\title{
Bovine conceptus of Bos indicus produced by somatic cell nuclear transfer and parthenogenesis present morphological variations since the blastocyst stage
}

\author{
[Conceptos bovinos (Bos indicus) produzidos por transferência nuclear de células somáticas \\ e partenogênese apresentam variações morfológicas desde o estágio de blastocisto] \\ F.D. Oliveira ${ }^{1}$, J.R. Sangalli ${ }^{2}$, F.V. Meirelles ${ }^{2}$, F. Perecin ${ }^{2}$, P.P.C. Silva Filho ${ }^{3}$, \\ Y.F. Watanabe ${ }^{4}$, M.A. Miglino ${ }^{1}$, A.C. Assis Neto ${ }^{1}$ \\ ${ }^{1}$ FMVZ-USP - São Paulo, SP \\ ${ }^{2}$ FZEA-USP - Pirassununga, SP \\ ${ }^{3}$ Facoltà di Agraria - UNITO.- Grugliasco (TO), Italia \\ ${ }^{4}$ Autônomo - Cravinhos, SP
}

\begin{abstract}
In cattle, embryo development is characterized by the appearance of two distinct cell layers, the trophectoderm and the inner cell mass. The latter will undergo differentiation to form the embryonic disc consisting of the epiblast and hypoblast. The aim of this study was to ultrastructurally characterize the bovine embryo from different in vitro production techniques, with emphasis on trophectoderm and inner cell mass cells. Bovine embryos on day 7 (conception $=\mathrm{D} 1$ ) of pregnancy, derived via in vitro production techniques, were fixed for light and transmission electron microscopy processing. Results suggested that embryos produced by nuclear transfer of somatic cells and parthenogenesis showed significant changes in macroscopic and microscopic structure. Size was reduced, and the inner cell mass had no defined shape. Furthermore, organelles responsible for the absorption processes, communication, growth, and cellular metabolism were fewer and had changes in shape, when compared to results in embryos produced by in vitro fertilization. We concluded that embryos produced by parthenogenesis and SCNT exhibit morphological differences when compared with IVF embryos, such as undeveloped blastocoel, poorly defined distribution of ICM, and morphological differences in organelles.
\end{abstract}

Keywords: embryo, blastocyst, in vitro production, ultrastructure

\section{RESUMO}

Em bovinos, o desenvolvimento embrionário é caracterizado pelo surgimento de duas camadas distintas, o trofectoderma e a massa celular interna. Este último irá sofrer diferenciação para formar o disco embrionário, o qual consiste em epiblasto e hipoblasto. O objetivo deste estudo foi caracterizar ultraestruturalmente o embrião bovino proveniente de diferentes técnicas de produção in vitro, com ênfase no trofectoderma e na massa celular interna. Embriões bovinos com sete dias de gestação (fecundação = D1), derivados de técnicas de produção in vitro, foram fixados para processamento de microscopia de luz e eletrônica de transmissão. Os resultados sugerem que os embriões produzidos por transferência nuclear de células somáticas e partenogênese apresentaram alterações significativas em suas estruturas macro e microscópica. O tamanho foi reduzido, e a massa celular interna não tinha uma forma definida. Além disso, organelas responsáveis por processos de absorção, comunicação, crescimento e metabolismo celular estavam em menor número e tinham alterações na forma quando comparadas aos resultados em embriões produzidos por fertilização in vitro. Conclui-se que os embriões produzidos por SCNT e partenogênese apresentam diferenças morfológicas quando comparados aos embriões de fertilização in vitro, tais como blastocele pouco desenvolvida, massa celular interna pouco definida e diferenças morfológicas nas organelas.

Palavras-chave: embrião, blastocisto, produção in vitro, ultraestrutura

Recebido em 9 de maio de 2014

Aceito em 27 de março de 2015

E-mail:delys@usp.br 


\section{INTRODUCTION}

The embryo in the blastocyst stage receives much attention because cell groups that constitute the trophectoderm (TE) and inner cell mass (ICM), are responsible for the formation of embryonic attachments and the complete organism, respectively. The inner cell mass consists mainly of stem cells capable of differentiating into any body tissue (Morris et al. 2010; Oestrup et al., 2010). By D12 of bovine development, it has differentiated into two cell types: the epiblast, which retains characteristics of pluripotent stem cells and participates in the formation of the three germ layers, and the hypoblast that participates in the formation of the endoderm and yolk sac (Vejlsted et al., 2005; Rossant et al. 2007).

It has been reported that embryos produced by in vitro fertilization (IVF) can develop into normal animals (Farin et al., 2006). However, cases of malformation beginning in the earliest stages of pregnancy have also been found (Mohr and Trounson, 1982; Camargo et al., 2005). This occurs mainly in embryos produced by IVF, somatic cell nuclear transfer (SCNT) and parthenogenesis. Changes in these embryos are morphological and chromosomal, leading to abnormal gene expression (Gjorret et al., 2005; Zhou et al., 2008). It is believed that these abnormalities and placental dysfunction are the main causes of embryonic loss in the embryonic period (Hill et al., 2000; Talbot et al., 2000; Maddox-Hyttel et al., 2003; Tveden-Nyborg et al., 2005; Alexopoulos et al., 2008).

In embryos not produced by natural mating, high pregnancy loss occurs in the transition from the choriovitelline placenta to the chorioallantoic placenta, suggesting that changes present in this embryonic attachment may cause this high rate of embryonic loss. Such information emphasizes the importance of studies in groups of embryos produced using various techniques. Thus, the study of the inner cell mass and trophectoderm structure can provide means to identify morphological changes in IVF, SCNT and parthenogenetic embryos, aiming toward future studies designed to modify the changes, perhaps decrease bovine pregnancy loss, and thereby generate a net economic gain (Arnold et al., 2006; Assis Neto et al., 2010; Berg et al., 2010; Assis Neto et al., 2011).
The aim of this study was to ultrastructurally characterize the trophectoderm and the inner cell mass cells of the bovine embryo in the blastocyst stage of development.

\section{MATERIALS AND METHODS}

This work has been submitted and approved by the Ethics Committee on the use of animals in the Veterinary Medicine and Animal Science School of the University of São Paulo, under protocol number 2655/2012.

Obtaining of embryos: a total number of 21 bovine embryos (B. indicus) were used. Embryos produced by in vitro fertilization and aged 07 (D7) days were used. The D7 $(n=7)$ embryos were in a culture medium and were fixed directly. A stereomicroscope was used to evaluate and identify embryos, as well as prepare for fixation procedures. In addition, we also used D7 $(n=7)$ embryos derived from SCNT and parthenogenesis $(n=7)$. These embryos were produced from oocytes obtained from ovaries collected at the local abattoir. Oocytes were denuded of cumulus cells and, according to the presence of the first polar body, were used for nuclear transfer. Then, oocytes were enucleated and reconstructed after injection of a fibroblast into the perivitelline space. The technique details can be seen in the work of Sangalli et al. (2012).

Fixation of embryos: The D7 embryos were fixed in $2.5 \%$ glutaraldehyde for 48 hours at $4^{\circ} \mathrm{C}$. All processing was performed with the aid of a stereomicroscope Leica S6E (Houston, TX, USA) for better viewing of embryos.

Transmission electron microscopy - Tem: after fixing, embryos were washed in PBS and placed in a osmium tetroxide (OsO4) $1 \%$ solution with a sodium phosphate buffer (Sigma Chemical Co. St. Louis, MO, USA) for 2 hours at room temperature. After further washing in PBS, embryos were contrasted with uranyl acetate overnight. Then, embryos were dehydrated in increasing concentrations of ethanol $(70,80,90$, 95 and $100 \%$ ), for half hour in each concentration, and subsequently washed with propylene oxide. Samples were rotated between mixtures of propylene oxide and Spurr resin at a ratio of $1: 1$ for $4 \mathrm{~h}$. This mixture was subsequently replaced with pure resin overnight. Embryos were embedded in new pure resin molds and kept 
in an oven at $70^{\circ} \mathrm{C}$ for $72 \mathrm{~h}$ to solidify the resin polymerization.

In order to locate areas of interest, blocks were serially cut with an ultramicrotome. Semithin slices $(400 \mathrm{~nm})$ were removed and stained with toluidine blue for light microscope observation. Ultrathin sections (approximately 70nm) were made with a Leica Ultracut UCT ultramicrotome ${ }^{\circledR}$ (Wetzlar, German). Materials were harvested on copper screens and contrasted with uranyl acetate $(2 \%)$ in distilled water for 5 minutes and lead citrate $(0.5 \%)$ in distilled water for 10 minutes. The semithin sections were observed and photographed under an Olympus DP71 microscope (Center Valley, PA, USA), and the ultrathin ones were analyzed with a Morgagni 268D microscope (FEI - Tokyo, Japan).

\section{RESULTS}

Macroscopically, at D7, IVF, SCNT and parthenogenetic embryos were spherical with an expanded blastocyst cavity surrounded by a single trophectoderm layer. Internally, the ICM was distinctly located at the embryonic poles (Figure 1A). It was not possible to determine whether hypoblast development had begun. Some embryos were still surrounded by the zona pellucida, and others were hatching or already completely free of the glycoprotein layer (Figure 1B). Embryos still contained in the zona pellucida were markedly smaller than hatched embryos.

Generally, D7 embryos produced in vitro were in the early blastocyst stage characterized by a spherical shape and the presence of the trophectoderm surrounding the well-formed blastocyst cavity as well as the inner cell mass. Somatic cell nuclear transfer embryos (Figure 2A) and parthenogenetic (Figure 2B), despite being the same age as the IVF embryos (Figure 2C), showed mild developmental delay, evident in the blastocoel size and the thick zona pellucida still covering the whole embryo. In IVF embryos, the zona pellucida was also present, but very thin and narrowing as the blastocoel expanded. In these blastocysts, trophectoderm cells were well stratified, delimiting the blastocyst cavity, and cells of the inner cell mass had concentrated at one embryonic pole, clearly indicating development beyond that of the other blastocysts. Already in SCNT and parthenogenetic embryos, the ICM was a diffuse shape scattered along the blastocoel. In none of the embryos was there evidence of differentiation of inner cell mass cells.

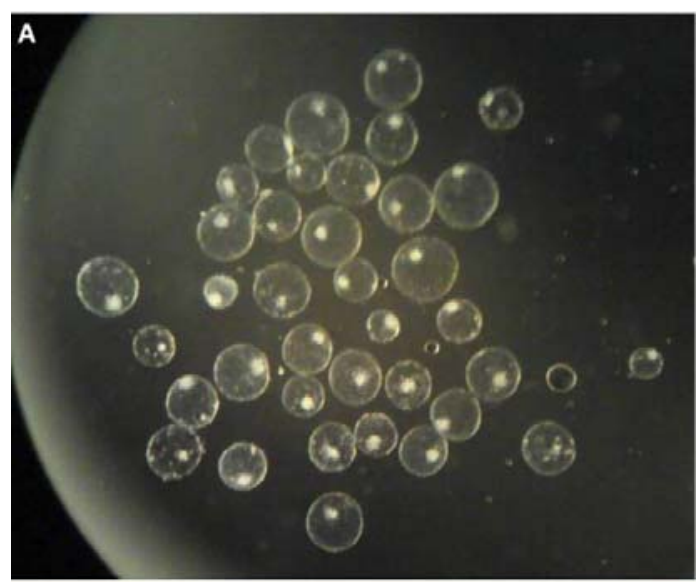

B

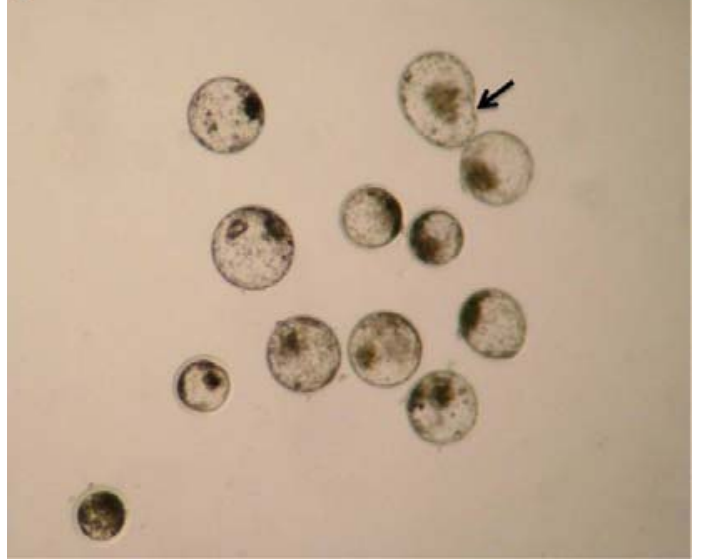

Figure 1. Photograph of IVF embryos D7. In A, embryos in the plate growing before fixation. In $\mathrm{B}$, embryo hatching process - loss of zona pellucida - (arrow).

The IVF embryos displayed major cell membrane specializations. Some microvilli were found in trophectoderm cells at the surface in contact with the zona pellucida (Figure 3A). Similarly, specialized ICM cells were also identified at the surface in contact with the trophectoderm, but in greater quantities (Figure 3D). Between trophectoderm and ICM cells were gap junctions on the lateral surface. Desmosomes were also present, but these provided contact between the ICM and the trophectoderm cells (Figure 3E). Among the cytoplasmic specializations were lipid droplets in both cell 
types, but in larger quantity in trophectoderm cells (Figure 3D). Secretory vesicles of various sizes were abundantly distributed throughout the cytoplasm (Figure 3B). A formation resembling a cortical granule was identified in the cytoplasm near the nuclear membrane (Figure 3C). Lysosomes or phagosomes were not seen in these embryos; nonetheless, mitochondria were numerous and polymorphic, ranging from an ovoid shape to a more elongated shape. Most of these organelles displayed normal morphology, but in some mitochondria of the ICM cells there was the formation of inside vacuoles and the presence of a very dense mitochondrial matrix, characteristic of immature mitochondria (Figure 3D and E). A limited number of intermediate filaments were found near the desmosomes. Rough endoplasmic reticulum (RER) was found in small quantities in the ICM cells, located next to the nucleus (Figure 3C). The cell nuclei of these embryos showed decondensed chromatin and large nucleoli (usually two) in both trophectoderm and ICM cells (Figure 3C).

In SCNT embryos, microvilli were present, particularly in surface trophectoderm cells in contact with the zona pellucida (Fig. 4C). The main forms of cellular communication were gap junctions between cells in the ICM and trophectoderm (Figure 4E). Unlike IVF embryos, no desmossomes were observed. Also, no lipid droplets were found in these cells, but secretory vesicles were present and in notably larger quantities (Figure 4B). Cortical granules were also identified near the plasma membrane of ICM cells (Figure 4E). Mitochondria were irregular shaped in trophectoderm cells and ovoid in ICM cells. In both cases the matrix was dense, and ridges were clearly visible (Figure 4C). Configurations similar to the Golgi apparatus were found in trophectoderm cells (Figure 4D) and the endoplasmic reticulum was not identified, unlike IVF embryos. Nuclei cells were large, but only one nucleolus was observed, also in contrast to the IVF embryos. Moreover, nucleolar bodies, precursors to the nucleus of trophectoderm cells were observable (Figure 4A).
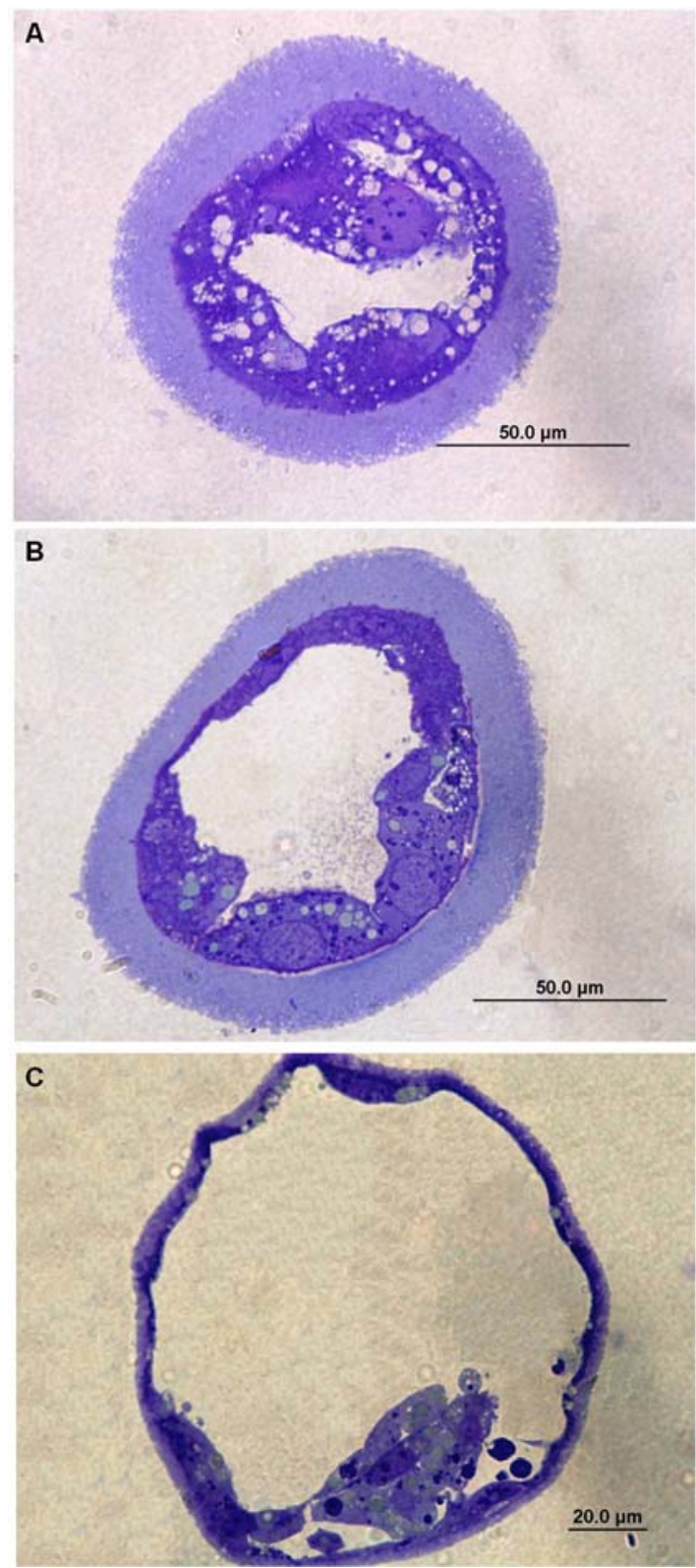

Figure 2. Photomicrograph of semithin cuts of D7 embryos. In A, SCNT embryo, B, parthenogenetic embryo, in C, IVF embryo. 

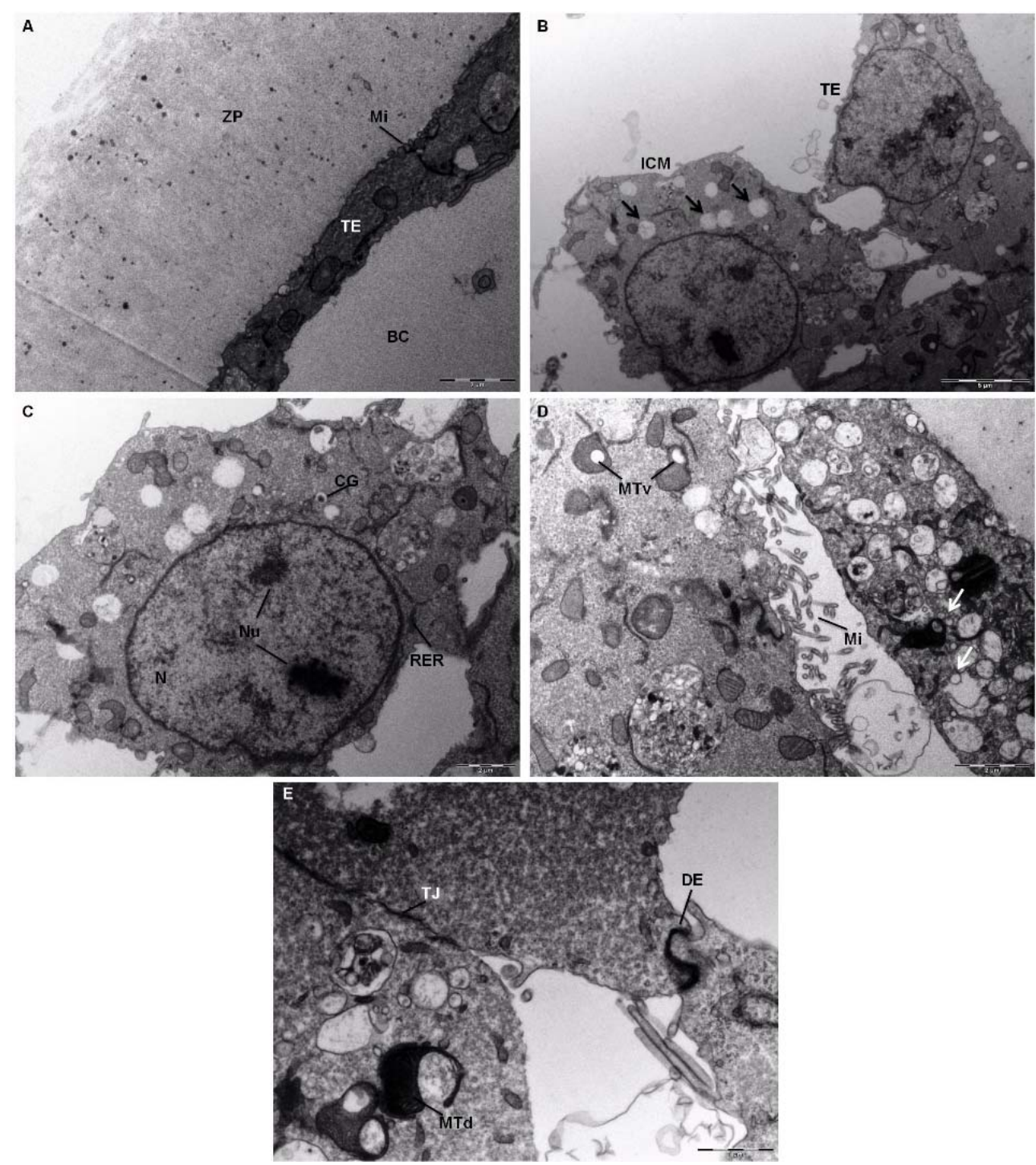

Figure 3. Transmission electron photomicrograph of bovine D7 embryo IVF. ZP - zona pellucida; TE trophectoderm, BC - blastocystic cavity; Mi - microvilli; ICM - inner cell mass; CG - cortical granules; RER - rough endoplasmic reticulum, N - nucleus; Nu - nucleolus; MTV - mitochondria with vacuoles; MTd - mitochondria with dense matrix; DE - desmosomes, TJ - tight junctions, black arrows - secretory vesicles; white arrows - lipid droplets.

The specializations of the plasma membrane in parthenogenetic embryos were similar to those observed in SCNT embryos. Extensive areas of microvilli in surface trophectoderm cells in contact with the zona pellucida were again present (Figure 5A). Gap junctions were present, but no desmosomes were found. The cytoplasm of parthenogenetic embryos showed the greatest changes. Lipid droplets, abundant in other types of embryos, were not present in any cell type, and secretory vesicles were present in very small number (Figure 5D). No cortical granules or organelles such as endoplasmic reticulum or Golgi apparatus were identified. Mitochondria showed major changes. They were ovoid, elongated, and irregular. Internally, mitochondrial ridges were not visible and vacuoles were often seen, particularly in the ICM cells (Figure 5B and C). The cell nuclei of these embryos showed a granular nucleoplasm without nucleolar precursor bodies. The nucleolus was present but not as evident as in other types of embryos (Figure 5A). 
DISCUSSION

Using light and transmission electron microscopy, this study described the morphology of bovine embryos derived from in vitro production techniques, and we inferred that the general morphology of these embryos did not differ from that found in other mammalian embryos, such as humans, rats, and sheep (Mohr and Trounson, 1982; Calarco and McLaren, 1976). However, several differences at the microscopic level could be observed when comparing the embryos with each other. In D7 embryos, the trophectoderm cells, which were well differentiated, demonstrated an important role in the formation and growth of the blastocyst because these depend on the acquisition and retention of fluids in the blastocoel (Massip et al., 1981). This characteristic was evident in IVF embryos, which demonstrated normal development.

Even so, D7 embryos differed in size due to the zona pellucida in smaller embryos. The zona pellucida prevented the embryo from growing in size, which happens only after hatching (McGeady et al., 2006; Maddox-Hyttel et al., 2010). The hatching process occurs by D7 of development, as observed in embryos used here.

In papers already published, the hypoblast fully present lined the blastocyst cavity at nine days, which leads us to the conclusion that their development begins around D7 and 8 (MaddoxHyttel et al., 2003). In our study, this cell layer was not yet forming in the D7 embryo, meaning that the inner cell mass was not differentiated into hypoblast and epiblast.
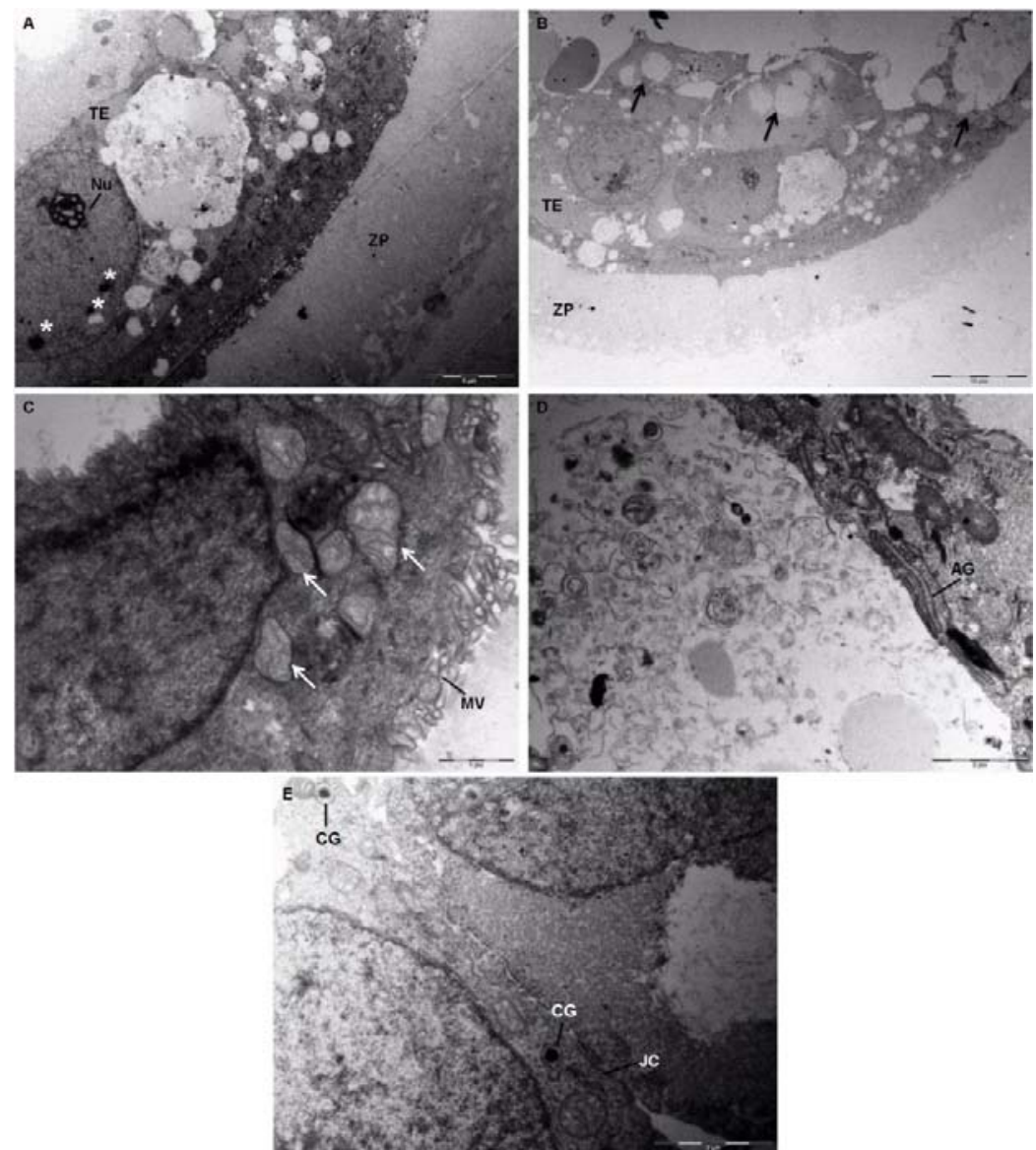

Figure 4. Electronic photomicrograph bovine D7 embryo SCNT. TE - trophectoderm; ZP - zona pellucida; $\mathrm{Nu}$ - nucleolus; GA - Golgi apparatus; Mi - microvilli; CG - cortical granules, TJ - tight junctions; asterisks - nucleolar precursor bodies, black arrows - secretory vesicles; white arrows mitochondria. 

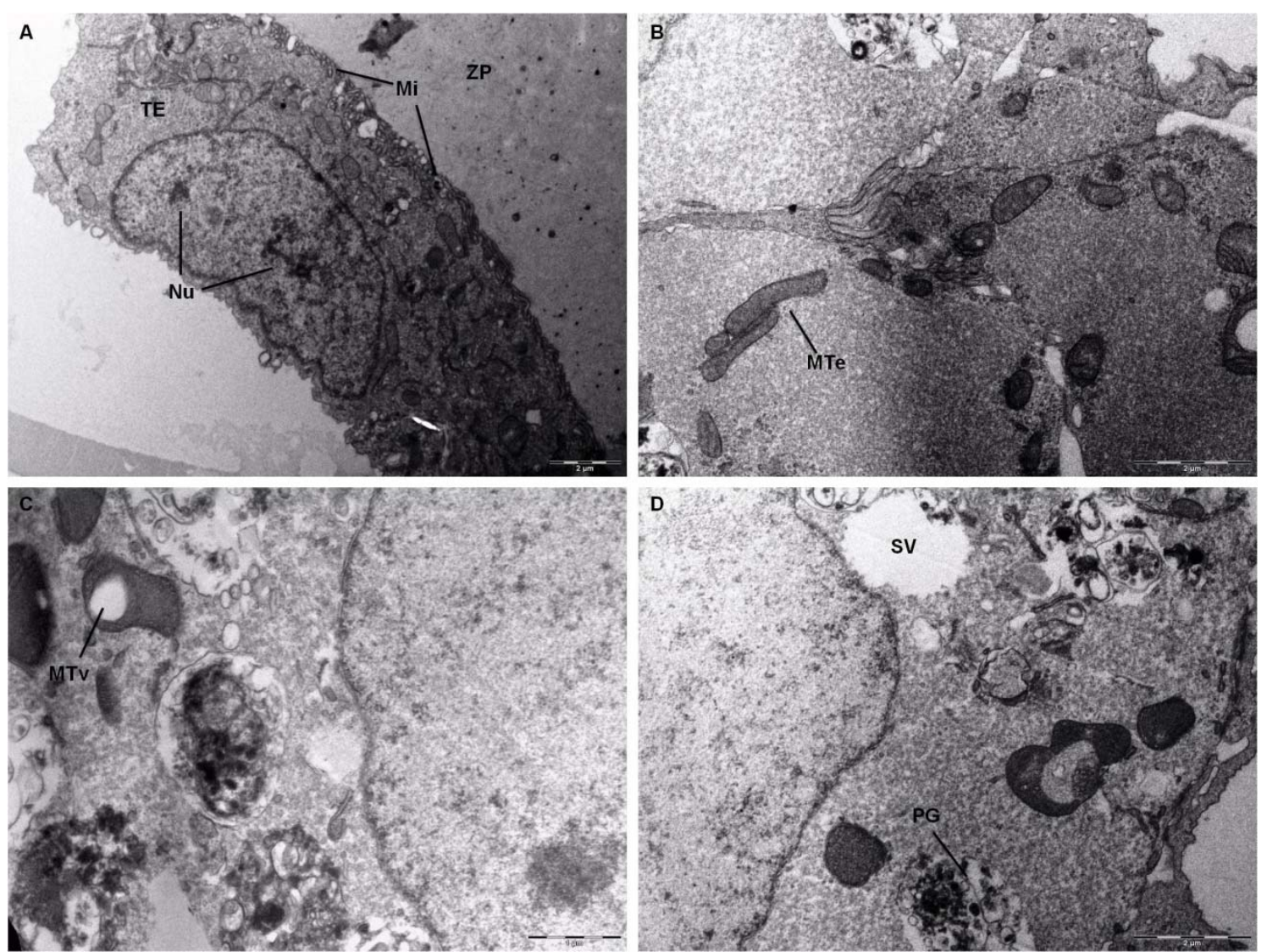

Figure 5. Electronic photomicrograph of bovine D7 embryo parthenogenetic. TE - trophectoderm; ZP zona pellucida; Mi - microvilli; $\mathrm{Nu}$ - nucleolus; MTe - elongated mitochondria; MTv - mitochondria with vacuoles, SV - secretory vesicle; PG - phagosome.

The ultrastructural analyzes performed here showed small differences in cell morphology of embryos produced via different techniques. In these embryos analyzed no apoptotic bodies or degenerative condition were found, as already seen in embryos derived from SCNT or parthenogenesis (Talbot et al., 2000).

Cells that constitute the embryo differed markedly from one another in form, arrangement, and organelles. This differentiation has been confirmed in other studies, which indicate that each cell group - trophectoderm, ICM, hypoblast or epiblast - has a specific role in embryonic development (Mohr and Trounson, 1982; Talbot et al., 2000).

Microvilli were present in all embryos studied here. These structures are responsible for increased absorption surface of cells and tissues, making them suitable for heavy transport of fluids and nutrients (Alberts et al., 2008).
Microvilli occurred in trophectoderm cells, as these cells absorb substances from the coelomic cavity. This characteristic has been observed not only in cattle, but in all mammalian blastocysts (Plante and King, 1994).

The presence of phagosomes is indicative of activity in cells that are in the process of differentiation. In this case, phagocytosis, which occurs through the action of lysosomal enzymes, is responsible mainly for removal of cellular debris characteristic of blastocyst formation (Talbot et al., 2000). Especially in parthenogenetic embryos, the presence of phagosomes suggested high degradation of cellular contents.

Communication structures between cell membranes, such as gap junctions and desmosomes, are also present in all mammalian blastocysts. The formation of such junction is important for maintaining adhesion and 
communication between cells, indeed characteristic of blastocysts at early stages of development, which are out of phase compression promoted by the presence of the zona pellucida; wherein the cells are in much closer point contact (Talbot et al., 2000; Maddox-Hyttel et al., 2003; Vejlsted et al., 2005). In embryos in the current study, such structures were well developed, although less so in SCNT and parthenogenetic embryos, indicating a deficiency in cellular communication.

The presence of secretory vesicles is well reported in the bovine species. This organelle, as well as lipid droplets found in cells of the embryos, is believed to be a source of energy and nutrients to the embryo in full development (Talbot et al., 2000). The cortical granules seen in SCNT and IVF embryos are typical of recently graduated zygotes as part of the process of blocking polyspermy. According Plant and King (1994) these granules undergo exocytosis, but their extended presence in the cytoplasm does not cause problems in embryo development.

Mitochondria are the organelles with the highest morphological variations among embryos. Their large numbers are an expected result due to high metabolic activity and protein synthesis in blastocyst cells. Differences in density of mitochondria may result from the amount of RNA present in it - the denser the mitochondria, the greater the amount of RNA. Vacuoles formed in the interior of the mitochondria may interfere with metabolism of the cell by increasing the surface area of the mitochondria and, consequently, increasing absorption of energy cytoplasm sources. Changes in the morphology of mitochondria have been noted in other studies with cattle and other species, and it is believed that these modifications also entail changes in the functionality of this organelle (Calarco and McLaren, 1976; Plante and King, 1994). The morphological changes can be related to changes in the metabolic activity of cells that also vary according to consumption of oxygen (Talbot et al., 2000). All such changes were present in D7 embryos, suggesting a quiescent cell state.

In summary, in D7 embryos produced via SCNT and parthenogenesis, the ICM was not well defined in the embryonic pole, and its size was smaller when compared to IVF embryos.
Notably, the main organelles involved in the absorption processes, communication, growth and cell metabolism were affected in number or in shape in embryos SCNT and parthenogenesis produced, indicating that these embryos may not have a normal development. In contrast, IVF embryos showed few changes at the microscopic level, exhibiting morphology similar to embryos produced by natural mating. These findings corroborate other studies (Calarco and McLaren, 1976; Massip et al., 1981; Mohr and Trounson, 1982; Plante and King, 1994; Talbot et al., 2000; Maddox-Hyttel et al., 2003;), which also analyzed the morphology of these types of embryos. However, ours was a pioneer study in comparing D7 embryos produced via the tree techniques discussed.

\section{CONCLUSIONS}

We concluded that embryos produced by parthenogenesis and SCNT exhibit morphological differences when compared with IVF embryos. The differences include: undeveloped blastocoel, poorly defined distribution of ICM, and morphological differences in organelles.

\section{ACKNOWLEDGEMENTS}

To CAPES for financing the research, to Vitrogen for supplying the embryos used in this study, and to Rose Kastelic for reviewing the paper.

\section{REFERENCES}

ALBERTS, B.; JOHNSON, A.; LEWIS, J. et al. Molecular biology of the cell. 5.ed. New York: Garland Science; 2008

ALEXOPOULOS, N.I.; MADDOX-HYTTEL, P.; TVEDEN-NYBORG, P. et al. Developmental disparity between in vitro-produced and somatic cell nuclear transfer bovine days 14 and 21 embryos: implications for embryonic loss. Reproduction, v.136, p.433-445, 2008.

ARNOLD, D.R.; BORDIGNON, V.; LEFEBVRE, R. et al. Somatic cell nuclear transfer alters periimplantation trophoblast differentiation in bovine embryos. Reproduction, v.132, p.279-290, 2006.

ASSIS NETO, A.C.; PEREIRA, F.T.V.; SANTOS, T.C. et al. Morpho-physical recording of bovine conceptus (Bos indicus) and placenta from days 20 to 70 of pregnancy. Reprod. Domest. Anim., v.45, p.760772,2010 
ASSIS NETO, A.C.; GALDOS, A.C.; MANÇANARES, A.C.F. et al. Abnormalities in bovine conceptus development during the embryonic phase after InVitro Fertilization (IVF) and cloning by nuclear transfer (NT). Acta Sci. Vet., v.39, p.223-226, 2011.

BERG, D.K.; van LEEUWEN, J.; BEAUMONT, S. et al. Embryo loss in cattle between days 7 and 16 of pregnancy. Theriogenology, v.73, p.250-260, 2010.

CALARCO, P.G.; MCLAREN, A. Ultrastructural observations of preimplantation stages of sheep. $J$. Embryol. Exp. Morphol., v.36, p.609-622, 1976.

CAMARGO, L.S.A.; POWELL, A.M.; VALE FILHO, V.R.; WALL, R.J. Comparison of gene expression in preimplantation bovine embryos produced by in vitro fertilization or somatic cell nuclear transfer. Reprod. Fertil. Dev., v.17, p.487-496, 2005.

FARIN, P.W.; PIEDRAHITA, J.A.; FARIN, C.E. Erros in development of fetuses and placentas from in vitro-produced bovine embryos. Theriogenology, v.65, p.178-191, 2006.

GJORRET, J.O.; WENGLE, J.; MADDOX-HYTTEL, P.; KING, W.A. Chronological apperance of apoptosis in bovine embryos reconstructed by somatic cell nuclear transfer from quiescent granulosa cells. Reprod. Domest. Anim., v.40, p.210-216, 2005.

HILL, J.R.; BURGHARDT, R.C.; JONES, K. et al. Evidence for placental abnormality as the major cause of mortality in first-trimester somatic cell cloned bovine fetuses. Biol. Reprod., v.63, p.1787-1794, 2000.

MADDOX-HYTTEL, P.; ALEXOPOULOS, N.I.; VAJTA, G.; et al. Immunohistochemical and ultrastructural characterization of the initial posthatching development of bovine embryos. Reproduction, v.125 p.607-623, 2003.

MADDOX-HYTTEL, P.; SINOWATZ, F.; VEJLSTED, M. Essentials of domestic animal embryology. London: Saunders Elsevier; 2010.

MASSIP, A.; MULNARD, J.; HUYGENS, R. et al. Ultrastructure of the cow blastocyst. J. Submicrosc. Cytol., v.13, p.31-40, 1981.
McGEADY, T.A.; QUINN, P.J.; FITZPATRICK, E.S.; RYAN, M.T. Veterinary embryology. Iowa: Blackwell Publishing; 2006.

MOHR, L.R.; TROUNSON, A.O. Comparative ultrastructure of hatched human, mouse and bovine blastocysts. J. Reprod. Fertil., v.66, p.499-504, 1982.

MORRIS, S.A.; TEO, R.T.Y.; LI, H. et al. Origin and formation of the first two distinct cells types of the inner cell mass in the mouse embryo. PNAS, v.107, p.6364-6369, 2010 .

OESTRUP, O.; GJOERRET, J.; SCHAUSER, K. et al. Characterization of bovine epiblast-derived outgrowth colonies. Reprod. Fertil. Dev., v.22, p.625$633,2010$.

PLANTE, L.; KING, W.A. Light and electron microscopic analysis of bovine embryos derived by in vitro and in vivo fertilization. J. Assist. Reprod. Genet., v.11, p.515-529, 1994.

ROSSANT, J. Stem cells and lineage development in the mammalian blastocyst. Reprod. Fertil. Dev., v.19, p.111-118, 2007.

SANGALLI, J.R.; DE BEM, T.H.; PERECIN, F.; et al. Treatment of nuclear-donor cells or cloned zygotes with chromatin-modifying agents increases histone acetylation but does not improve full-term development of cloned cattle. Cell Reprog., v.14, p.235-247, 2012.

TALBOT, N.C.; POWELL, A.M.; GARRETT, W.M. et al. Ultrastructural and karyotypic examination of in vitro produced bovine embryos developed in the sheep uterus. Tissue Cell, v.32, p.9-27, 2000.

TVEDEN-NYBORG, P.; PEURA, T.T.; HARTWICH, K.M. et al. Morphological characterization of pre- and peri-implantation in vitro cultured, somatic cell nuclear transfer and in vivo derived ovine embryos. Reproduction v.130, p.681694, 2005.

VEJLSTED, M.; AVERY, B.; SCHIMDT, M. et al. Ultrastructural and immunohistochemical characterization of the bovine epliblast. Biol. Reprod., v.72, p.678-686, 2005.

ZHOU, W.; XIANG, T.; WALKER, S. et al. Global gene expression analysis of bovine blastocysts produced by multiple methods. Mol. Rep. Dev., v.75, p.744-758, 2008. 